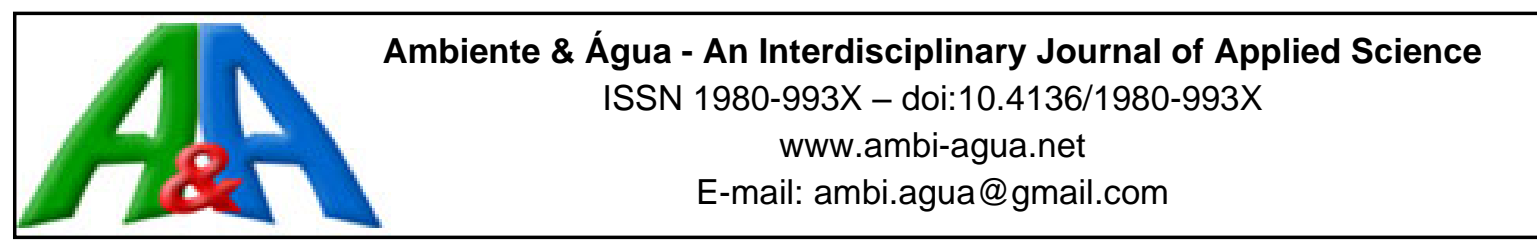

\title{
Metal phytosorption potential of Hydrocotyle ranunculoides for mitigation of water pollution in high Andean wetlands of Peru
}

\author{
ARTICLES doi:10.4136/ambi-agua.2535
}

Received: 24 Feb. 2020; Accepted: 28 Jul. 2020

\author{
Walter Javier Cuadrado Campó1(i); María Custodio ${ }^{2 *(D)}$; \\ Carmela Emperatriz Vicuña Orihuela ${ }^{1}$; Richard Pavel Peñaloza Fernández ${ }^{2}$ it \\ ${ }^{1}$ Universidad Nacional del Centro del Perú. Facultad de Ciencias Aplicadas, Carretera Central \\ Km 4.5, Tarma, Perú. E-mail: wjcuadrado@ hotmail.com, carmelavic@ hotmail.com \\ ${ }^{2}$ Universidad Nacional del Centro del Perú. Facultad de Medicina Humana. Centro de Investigación en Medicina \\ de Altura y Medio Ambiente, Avenida Mariscal Castilla nº 3089, Huancayo, Perú. \\ E-mail: drach_89@hotmail.com \\ "Corresponding author. E-mail: mcustodio@uncp.edu.pe
}

\begin{abstract}
The phytosorption potential of metals of Hydrocotyle ranunculoides was evaluated for the mitigation of water pollution in the high Andean wetlands of Peru. The plants were selected from 10 wetland sites in the community of Pomachaca- Tarma and were washed with potable water, dried, ground, weighed, chemically digested and read with Varian AA 240 atomic absorption equipment. The plant showed copper concentrations in the root $(12.08 \pm 1.67 \mathrm{mg} / \mathrm{kg})$ greater than the stem $(7.37 \pm 1.00 \mathrm{mg} / \mathrm{kg})$, followed by the leaves $(7.37 \pm 1.56 \mathrm{mg} / \mathrm{kg})$. Lead concentration in the root was $0.228 \pm 0.711 \mathrm{mg} / \mathrm{kg}$, but was not found in the stem or leaves. The highest zinc concentration was in the root $(67.52 \pm 12.57 \mathrm{mg} / \mathrm{kg})$ to the stem $(53.30 \pm 0.61$ $\mathrm{mg} / \mathrm{kg})$, followed by the leaves $(43.99 \pm 8.49 \mathrm{mg} / \mathrm{kg})$. Finally, iron was higher in the root $(5571.28 \pm 693.94 \mathrm{mg} / \mathrm{kg})$ than in the leaves $(342.76 \pm 122.09 \mathrm{mg} / \mathrm{kg})$, followed by the stem (291.94 $\pm 54.84 \mathrm{mg} / \mathrm{kg}$ ). Surrounding water had $\mathrm{pH}$ between 7.2 and 7.6; no copper and lead were found, zinc was $0.005 \pm 0.012 \mathrm{mg} / \mathrm{L}$ and iron was $0.009 \pm 0.007 \mathrm{mg} / \mathrm{L}$. In the sediment, copper was $26.12 \pm 0.65 \mathrm{mg} / \mathrm{kg}$, lead $28.25 \pm 2.41 \mathrm{mg} / \mathrm{kg}$, zinc $85.98 \pm 11.38 \mathrm{mg} / \mathrm{kg}$ and iron $26111.89 \pm 614.37 \mathrm{mg} / \mathrm{kg}$. These results indicate that this plant absorbs metals in the order of $\mathrm{Fe}>\mathrm{Zn}>\mathrm{Cu}>\mathrm{Pb}$ and is an alternative for the development of phytotechnology, oriented to the treatment of effluents with metals that contaminate water in wetlands.
\end{abstract}

Keywords: aquatic environment, heavy metal, Hydrocotyle ranunculoides, phytoabsorbing potential, pollution.

\section{Potencial de fitoabsorção de metais por Hydrocotyle ranunculoides para a mitigação de poluição de água nas áreas úmidas altas andinas do Peru}

\section{RESUMO}

O potencial de fitoabsorção de metais provenientes de Hydrocotyle ranunculoides foi avaliado para mitigar a contaminação da água nas áreas úmidas altas andinas do Peru. As plantas foram selecionadas de 10 zonas úmidas da comunidade de Pomachaca-Tarma e lavadas com água potável, secas, moídas, pesadas, quimicamente digeridas e lidas com o equipamento 
de absorção atómica Varian AA 240. A planta apresentava concentrações de cobre na raiz de $12.08 \pm 1.67 \mathrm{mg} / \mathrm{kg}$ seco, no caule de $7.37 \pm 1.00 \mathrm{mg} / \mathrm{kg}$ seco e nas folhas de $7.37 \pm 1.56 \mathrm{mg} / \mathrm{kg}$ seco. Quanto às concentrações de chumbo na raiz foi de $0.228 \pm 0.711 \mathrm{mg} / \mathrm{kg}$ seco, no caule e nas folhas não foi encontrado. O zinco mais elevado estava na raiz $67.52 \pm 12.57 \mathrm{mg} / \mathrm{kg}$ seco, no caule $53.30 \pm 0.61 \mathrm{mg} / \mathrm{kg}$ seco e seguido pelas folhas $43.99 \pm 8.49 \mathrm{mg} / \mathrm{kg}$ seco. Finalmente, o ferro era mais elevado na raiz com $5571.28 \pm 693.94 \mathrm{mg} / \mathrm{kg}$ seco, depois nas folhas 342.76 $\pm 122.09 \mathrm{mg} / \mathrm{kg}$ seco e seguido do caule $291.94 \pm 54.84 \mathrm{mg} / \mathrm{kg}$ seco. A água circundante tinha $\mathrm{pH}$ entre 7.2 e 7.6. Não foram encontrados cobre e chumbo, o zinco foi $0.005 \pm 0.012 \mathrm{mg} / \mathrm{L} \mathrm{e}$ o ferro $0.009 \pm 0.007 \mathrm{mg} / \mathrm{L}$. No sedimento, o cobre foi $26.12 \pm 0.65 \mathrm{mg} / \mathrm{kg}$ seco, o chumbo $28.25 \pm 2.41 \mathrm{mg} / \mathrm{kg}$ seco, o zinco $85.98 \pm 11.38 \mathrm{mg} / \mathrm{kg}$ seco e o ferro $26111.89 \pm 614.37 \mathrm{mg} / \mathrm{kg}$ seco. Estes resultados indicam que esta planta absorve metais na ordem de $\mathrm{Fe}>\mathrm{Zn}>\mathrm{Cu}>\mathrm{Pb}$ e é uma alternativa para o desenvolvimento da fitotécnica, orientada para o tratamento de efluentes com metais que contaminam a água em zonas úmidas.

Palavras-chave: ambiente aquático, Hydrocotyle ranunculoides, metais pesados, poluição, potencial de fitoabsorção.

\section{INTRODUCTION}

The pollution of the aquatic environment by potentially toxic contaminants has been of concern to humans for the last few decades (Mimba et al., 2018). Anthropogenic sources have been identified as significant contributors to environmental pollution problems (Väänänen $e t$ $a l ., 2018)$. As a result, ecosystems are damaged or altered by products containing heavy metals, such as copper $(\mathrm{Cu})$, calcium $(\mathrm{Ca})$, zinc $(\mathrm{Zn})$, manganese $(\mathrm{Mn})$ and iron $(\mathrm{Fe})$, many of which are essential micronutrients for plant metabolism, but when present in excess can become extremely toxic (Chatterjee et al., 2011). The importance of the environmental problem in modern society is the pollution of water by heavy metals that enter aquatic ecosystems through the discharge of wastewater from industrial, urban and agricultural runoff (Nazeer et al., 2014). Compared to organic contaminants, natural decomposition processes do not remove heavy metals.

In contrast, they can accumulate in aquatic biota and develop into organic complexes, which can potentially become more toxic (Mazej and Germen, 2009). The accumulation of metals by macrophytes is affected by the concentrations of metals in water and sediments and by the speciation of metals such as free ions and humic complexes (Kramer, 2010). Aquatic macrophytes are predominant organisms in lake ecosystems that, in comparison with other plant species, can absorb metals through their roots as well as through their leaves (Twardowska and Kyziol, 2003; Lojko et al.,2015). Hydrocotyle ranunculoides, as well as the cattail (Scirpus californicus) in the study area, serves as animal feed.

Tarma, a province of the Junin region, has a population whose main activity is agriculture and livestock. In the community of Pomachaca, cattle farmers feed their cattle with $H$. ranunculoides, which are contaminated with heavy metals. They use the manure of these animals in agriculture and their meat for food, causing possible damage to the health of the inhabitants. The objective of this study was to determine the phytosorption potential of metals from $H$. ranunculoides, to be used as an alternative to mitigate water pollution in high Andean wetlands in Peru.

\section{METHODS AND RESOURCES}

\subsection{Study area}

The study area is located in the province of Tarma in the central Andes of Peru, latitude

Rev. Ambient. Água vol. 15 n. 5, e2535 - Taubaté 2020 
$11^{\circ} 22^{\prime} 51.9^{\prime \prime} \mathrm{S}$ and longitude $75^{\circ} 41^{\prime} 12^{\prime \prime} \mathrm{W}$, at an altitude of 3031 masl (Figure 1). In wetlands of the area, Hydrocotyle ranunculoides is the predominant macrophyte and very important for the Pomachaca community, because their life activities depend on livestock and agriculture. Their livestock feed on these aquatic plants which, due to their characteristics, absorb heavy metals, compromising the health of the people who feed on the meat and milk of this livestock.

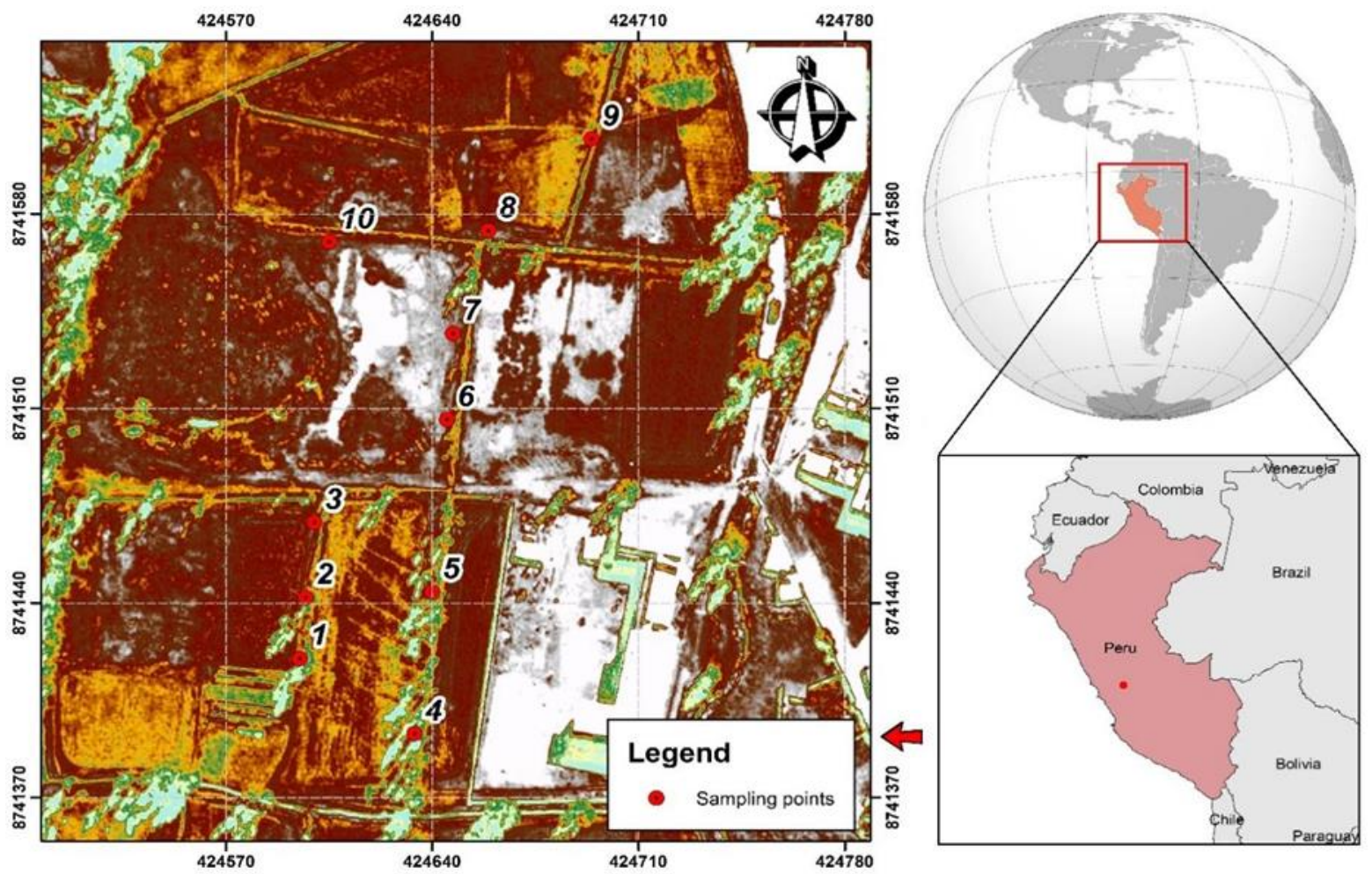

Figure 1. Location map of the study area in high Andean wetlands of Peru.

\subsection{Sampling and analysis of plants, sediment and water}

Ten sampling sites in the wetlands were selected; from each site three single samples were taken to form a composite sample of $3 \mathrm{~kg}$ of plants, passing a visual inspection, such as size, good physical condition and maturity (Figure 2). The water was collected from each sampling site in a one-litre volumetric glass bottle. Similarly, $2 \mathrm{~kg}$ of sediment sample was obtained in polyethylene bags. All samples, with their respective identification, were taken directly to the Chemistry and Environment Laboratory of the Universidad Nacional del Centro del Perú for their respective analyses.

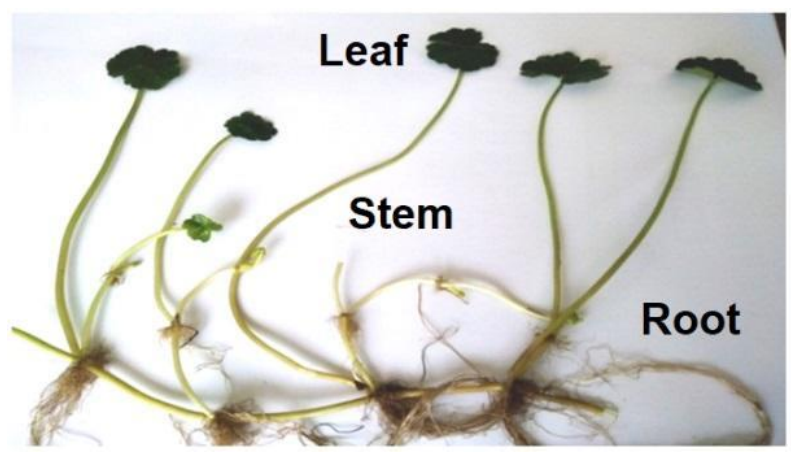

Figure 2. Macrophyte Hydrocotyle ranunculoides.

The determination of the concentration of metals in the plant, sediment and water was performed by chemical digestion with hydrochloric acid, nitric acid and chemically pure 
perchloric acid at $80^{\circ} \mathrm{C}$, according to the standardized method of atomic absorption (APHA $e t$ $a l .$, 2012), as shown in Figure 3.
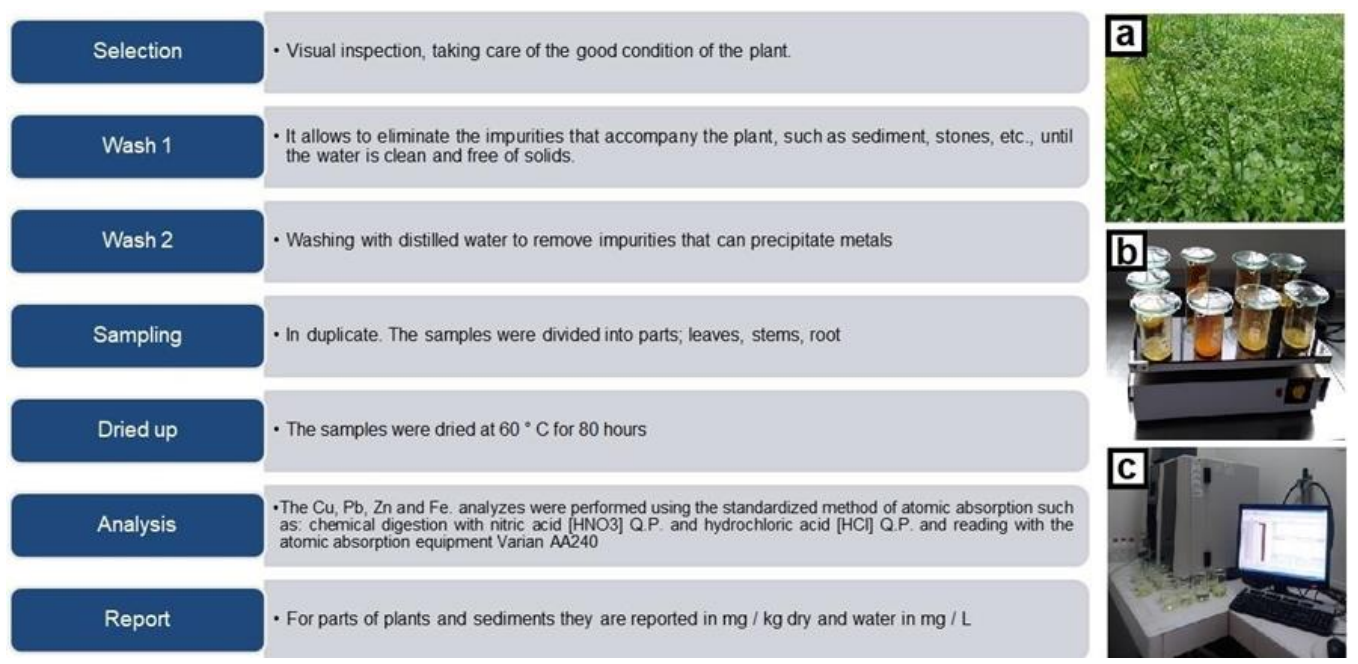

Figure 3. Flowchart of the evaluation of the Hydrocotyle ranunculoides plant: (a) sampling site, (b) sample digestion, (c) atomic absorption analysis.

\subsection{Analysis of data}

For the comparison of the concentration of each metal by the factor evaluated (water, sediment and plant part), the Kruskall Wallis test was used with a post hoc procedure (Kruskal and Wallis, 1952; Katz and Mcsweeney, 1980), with null hypothesis indicating statistical similarity in the concentrations of elements. To test the relationship between element concentrations in water and sediment with element concentrations in plant tissues, a redundancy analysis (RDA) was performed using Canoco software. RDA is used in ecology for management by direct gradient analysis, where a matrix of response variables, $\mathrm{Y}$, is analyzed with respect to a corresponding matrix of environmental variables, X (Gan et al., 2017). RDA can be described as a series of multiple regressions followed by a principal component analysis (Legendre and Andersson, 1999). Here, instead of one vector for one variable, y, we are analyzing a data matrix with many variables, Y. Each vector variable, y, is regressed on the matrix of dummy variables corresponding to the environmental variables, $\mathrm{X}$ (Legendre and Andersson, 1999).

\section{RESULTS AND DISCUSSION}

The plant, like any living being, has the capacity to absorb or adsorb substances such as heavy metals. However, many of them are beneficial for its subsistence, while others are harmful to its physiological processes. The heavy metal contents in the samples are listed in Table 1, for each part of the plant evaluated (leaf, stem and root) and each characteristic of the growing environment (water and sediment). It should be noted that, in order of concentration, Fe is significantly higher in all the factors under study $(\mathrm{p}<0.05)$, with the logical sequence of concentration $\mathrm{Fe}>\mathrm{Zn}>\mathrm{Cu}>\mathrm{Pb}$, for all the factors under study. Because $H$. ranunculoides, like other macrophytes, absorb $\mathrm{Cu}, \mathrm{Pb}, \mathrm{Zn}$ and $\mathrm{Fe}$ (Cuadrado et al., 2019). This behavior is due to the greater capacity of plants to absorb micronutrients compared to non-essential or toxic elements, for which plants can generate tolerance strategies (Kabata-Pendias, 2011).

A range of $\mathrm{Zn}$ concentrations between 70 and $400 \mathrm{mg} / \mathrm{Kg}$ could be considered toxic to plants, while the level of toxic $\mathrm{Zn}$ in plant tissue is $23 \mathrm{mg} / \mathrm{Kg}$ tolerance (Kabata-Pendias, 2011; Li et al., 2009). This plant has the capacity to absorb significant amounts of Fe in its leaves and stems and the largest amount was in the root. The tolerance of plants to high concentrations of 
heavy metals is determined by several internal and external factors, such as phenology, vigor, growth, speciation of elements and water chemistry (Yang and Ye, 2009). Pb, is more toxic than other metals and immobile due to its strong bond with organic matter and other plant components (Aksoy et al., 2005; Kastratović et al., 2013). The results obtained are supported by Zevallos et al. (2015), who report that the accumulation of $\mathrm{Pb}^{2+}$ in plants is regulated by physicochemical parameters such as the $\mathrm{pH}$ of the medium, the presence of exudates, the cation exchange capacity of its surface, etc. Vascular plants absorb and accumulate $\mathrm{Pb}^{2+}$ mainly in the roots and only a small part moves to the air part (Marmiroli et al., 2005).

Table 1. Mean heavy metal concentration in plants, sediments and water in the study area $(\mathrm{mg} / \mathrm{L}$ water and $\mathrm{mg} / \mathrm{Kg}$ sediment and plant).

\begin{tabular}{ccccccccccccccccc}
\hline & \multicolumn{3}{c}{ Leaf } & \multicolumn{4}{c}{ Stem } & \multicolumn{4}{c}{ Root } & \multicolumn{3}{c}{ Sediment } & \multicolumn{3}{c}{ Water } \\
\hline & Mean & & SD & Mean & & SD & Mean & & SD & Mean & SD & Mean & SD \\
\hline Copper & $7.37^{\mathrm{c}}$ & \pm & 1.56 & $7.37^{\mathrm{c}}$ & \pm & 1 & $12.08^{\mathrm{b}}$ & \pm & 1.67 & $26.12^{\mathrm{a}}$ & \pm & 0.65 & $0 \mathrm{~d}$ & \pm & 0 \\
Lead & $0^{\mathrm{c}}$ & \pm & 0 & $0^{\mathrm{c}}$ & \pm & 0 & $0.226^{\mathrm{b}}$ & \pm & 0.711 & $28.25^{\mathrm{a}}$ & \pm & 2.412 & $0^{\mathrm{c}}$ & \pm & 0 \\
Zinc & $43.9^{\mathrm{d}}$ & \pm & 8.49 & $53.3^{\mathrm{c}}$ & \pm & 0.61 & $67.52^{\mathrm{b}}$ & \pm & 12.57 & $85.98^{\mathrm{a}}$ & \pm & 11.38 & $0.005^{\mathrm{e}}$ & \pm & 0.012 \\
Iron & $342.8^{\mathrm{c}}$ & \pm & 122.1 & $291.9^{\mathrm{c}}$ & \pm & 54.84 & $5571^{\mathrm{b}}$ & \pm & 693.9 & $26112^{\mathrm{a}}$ & \pm & 614.4 & $0.009^{\mathrm{d}}$ & \pm & 0.007 \\
\hline
\end{tabular}

* Kruskal Wallis analysis, where the different letters as coefficient in the mean (a, b, c, d and e) show significant difference against the mean value of each heavy metal $(p<0.05)$ due to the effect of the location factor (leaf, stem, root, sediment and water).

Table 1 shows the results of the Kruskall Wallis test, summarizing and comparing the concentrations of the four metals evaluated in different parts of the plant (stem, leaf and root), water and sediment. The distribution of the concentrations shows significant differences depending on the part of the plant evaluated as being superior to the average values of each element evaluated. A similar behavior to the transfer factor is observed, both for the concentration of metals in the roots and leaves with respect to their environment (water and sediment). Therefore, the analysis was given according to these last two factors, since the concentrations of elements found in the plant respond to the concentration of elements from its development environment.

The results show that, in the case of $\mathrm{Cu}$, the root tends to significantly absorb this metal, since the disparities in concentrations tend to be half of what is reported in the sediment. However, the distribution of this metal along the leaves and the stem with concentrations of 7 to $8 \mathrm{mg} / \mathrm{kg}$ for both is one third of what is reported in the sediment. In addition, the $\mathrm{Cu}$ concentrations detected in the sediment are significantly higher than those recorded in the other factors under study, either in the water or in the plant parts.

In the case of lead, the Kruskal Wallis analysis shown in Table 1 indicates that concentrations in the sediment are significantly higher than reported. The capacity of the plant to absorb lead is not significant, although there is a slope that the root absorbs much more lead from the sediment and that lead is not distributed along the leaf and stem. However, no lead concentrations were reported in the water. The case of zinc tends to have a similar distribution in relation to the absorption and distribution of copper, probably because they are essential metals and are more easily distributed. While it is true that zinc concentrations in water are significantly lower $(0.005 \pm 0.012 \mathrm{mg} / \mathrm{kg})$, there is no inclination for zinc and copper elements to have been absorbed from water. In general, a higher absorption of metals is observed in relation to the sediment. It is observed that copper shows a distribution that tends to be significant in the stem and leaf compared to the concentration in the root, while iron and lead tend to be concentrated in the root.

Table 2 shows the maximum permissible limits of heavy metals in water and sediments, showing that the average of the metals evaluated and detected in water are significantly lower than the maximum allowed $(\mathrm{p}>0.05)$. However, in the sediment it was found that the average 
copper concentration was significantly higher than the maximum allowed value $(\mathrm{p}<0.05)$; while the average concentrations of the other elements are less or equal to the maximum allowed.

Table 2. Permissible levels of heavy metals in various components of international agencies ( $\mathrm{mg} / \mathrm{L}$ water and $\mathrm{mg} / \mathrm{Kg}$ sediment).

\begin{tabular}{ccccccc}
\hline Factor & International agencies & $\mathbf{C u}$ & $\mathbf{P b}$ & $\mathbf{Z n}$ & $\mathbf{F e}$ & Reference \\
\hline \multirow{2}{*}{ Water } & EPA & 0.007 & 0.01 & 0.086 & 0.3 & Nazeer et al. (2014) \\
\multirow{2}{*}{ Sediment } & WHO & 2 & 0.01 & 3 & 0.3 & WHO (1993) \\
& CEQG & 18.7 & 30.2 & 124 & NA & CEQG (2001) \\
\hline
\end{tabular}

Redundancy analysis of correlations between plant metal concentrations and environmental factors are presented in the biplot for each plant part and environmental factor studied. Figure 4A shows the correlation between the matrices of the distribution of metal concentrations in the water and leaf independently. The eigenvalues for the first and second coordinates are 0.79 and 0.0082 ; i.e., the explained variation of what happens in the original data can only be interpreted as a function of the first common axis $79.45 \%$, since the second axis has a low level of explained variation of $0.82 \%$. The PCO 1 tends to have a higher correlation with the $\mathrm{X}$ axis, and whose vector is wider. In addition, the analysis indicates that Sample 1 is the one that mainly determines the distribution of environmental and biological vectors with respect to the concentration of metals. Direct selection redundancy analysis of the table indicates that the concentrations of zinc and iron present in the leaf correlate with the distribution of zinc and iron concentrations in the water; although the iron vector tends to have a different orientation, it is the weight of the second coordinate that determines that orientation is not significant.

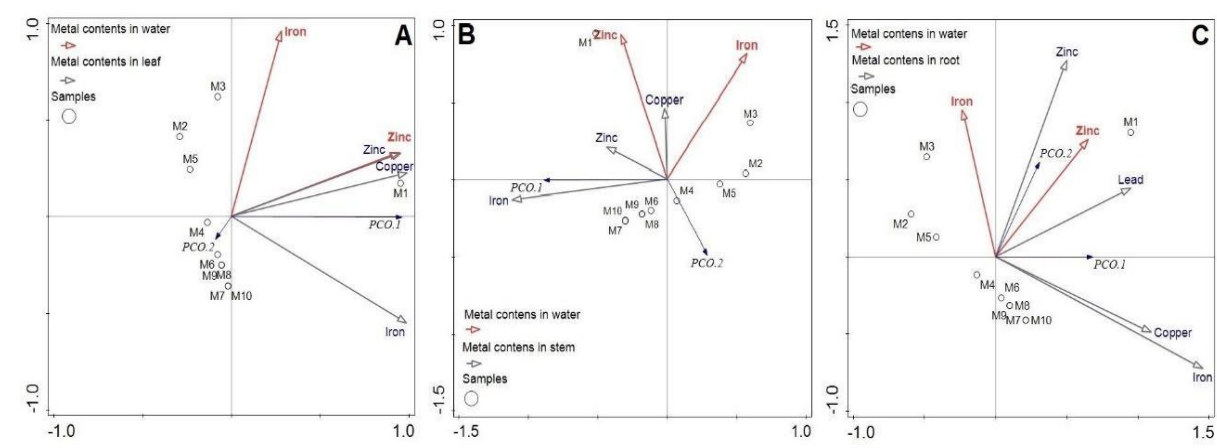

Figure 4. Redundancy analysis of the correlations between the metal content in leaves (blue lines), total metal concentrations in water (red lines) and vector direction of the first two coordinates (black lines).

For the correlation of the concentration of metals present in the water and in the plant stem, Figure 4B shows the same distribution trend and behavior pattern of the samples, and the coordinates tend to have the same loads. Coordinate one was found to have an explained variation of $77.02 \%$, and the second coordinate of only $0.96 \%$, with the latter not being very relevant in the interpretation. The analysis shows the interaction of the two matrices of metal concentrations in the water and in the stem, finding that it is ample 1 that determines the distribution of the observations.

Table 3 shows Zinc as the only element that tends to correlate with its pair for both water and stem in relation to its concentrations, indicating that zinc is the only element that is significantly transferred from water to the stem. For the correlation of the element concentrations of the water that are transferred to the root, Figure $4 \mathrm{C}$ shows redundancy analysis of the integration of the two matrices, showing that the loads for the first and second 
coordinates are significantly lower compared to the correlation of the leaves and stems. The first coordinate has an explained variation of $47.1 \%$ and the second coordinate has a significantly lower variation of $0.01 \%$. This is due to the fact that the distributions of the samples do not tend to correspond for both matrices, and as shown in Table 3, in the direct selection redundancy analysis neither of the elements that present concentrations of zinc or iron in the water presents a significant correspondence in relation to the distribution of the concentrations in the root of the plant; that is to say that the concentrations of elements found in the water tend to explain the concentration of elements found in the root of the plant.

Table 4 shows the direct selection redundancy analysis for the correlation of metal concentration matrices in the plant explained by the sediment. The first analysis of metal concentration in sediment and the correlation of the distribution of the samples for the metal content in the leaves is summarized in Figure 5A. The redundancy analysis indicated that the load for the first coordinate was $82.89 \%$ variation explained and the second a load of $2.41 \%$. The biplot indicates that Sample 1 determines the distribution of the observations in relation to the others, although there is a tendency for horizontal ordering favored by the trajectory of the first coordinate. The perceptual map shows that $\mathrm{Cu}, \mathrm{Fe}$ and $\mathrm{Pb}$ in sediment have a negative correlation, while in the concentration in the leaf there is a certain tendency of positive correlation between $\mathrm{Cu}$ and $\mathrm{Zn}$. Direct selection redundancy analysis indicates that $\mathrm{Zn}$ is the only element that tends to bioaccumulate significantly in leaves.

Table 3. Redundancy analysis based on distance, step by step direct selection for water factor.

\begin{tabular}{ccccc}
\hline Name & Explains \% & Contribution \% & pseudo-F & P \\
\hline \multicolumn{5}{c}{ Forward Selection Results: Water - root } \\
\hline $\mathrm{Zn}$ & 20 & 42.5 & 2 & 0.206 \\
$\mathrm{Fe}$ & 27.1 & 57.5 & 3.6 & 0.092 \\
\hline \multicolumn{5}{c}{ Forward Selection Results: Water - stem } \\
\hline $\mathrm{Fe}$ & 25.9 & 33.2 & 2.8 & 0.122 \\
$\mathrm{Zn}$ & 52.1 & 66.8 & 16.6 & 0.012 \\
\hline \multicolumn{5}{c}{} \\
\hline $\mathrm{Zn}$ & 70.8 & 88.2 & 19.4 & 0.04 \\
$\mathrm{Fe}$ & 9.5 & 11.8 & 3.4 & 0.038 \\
\hline
\end{tabular}

Table 4. Redundancy analysis based on distance, step by step direct selection for sediment factor.

\begin{tabular}{lcccc}
\hline Name & Explains \% & Contribution $\%$ & pseudo-F & P \\
\hline \multicolumn{5}{c}{ Forward Selection Results:Sediment - root } \\
\hline $\mathrm{Pb}$ & 57.3 & 65.2 & 10.7 & 0.068 \\
$\mathrm{Zn}$ & 22 & 25.1 & 7.5 & 0.01 \\
$\mathrm{Fe}$ & 6.1 & 7 & 2.5 & 0.092 \\
$\mathrm{Cu}$ & 2.5 & 2.8 & 1 & 0.342 \\
\hline \multicolumn{5}{c}{ Forward Selection Results: Sediment - stem } \\
\hline $\mathrm{Pb}$ & 26.9 & 62.2 & 2.9 & 0.12 \\
$\mathrm{Fe}$ & 15.4 & 35.6 & 1.9 & 0.252 \\
$\mathrm{Zn}$ & 0.8 & 1.8 & $<0.1$ & 0.856 \\
$\mathrm{Cu}$ & 0.1 & 0.3 & $<0.1$ & 0.988 \\
\hline \multicolumn{5}{c}{} \\
\hline $\mathrm{Zn}$ & Forward Selection Results: Sediment -1 leaf & \\
$\mathrm{Cu}$ & 56.9 & 66.6 & 10.6 & 0.048 \\
$\mathrm{Fe}$ & 16.9 & 19.8 & 4.5 & 0.058 \\
$\mathrm{~Pb}$ & 7.2 & 8.4 & 2.3 & 0.146 \\
$\mathrm{~F}$ & 4.5 & 5.3 & 1.5 & 0.228 \\
\hline
\end{tabular}




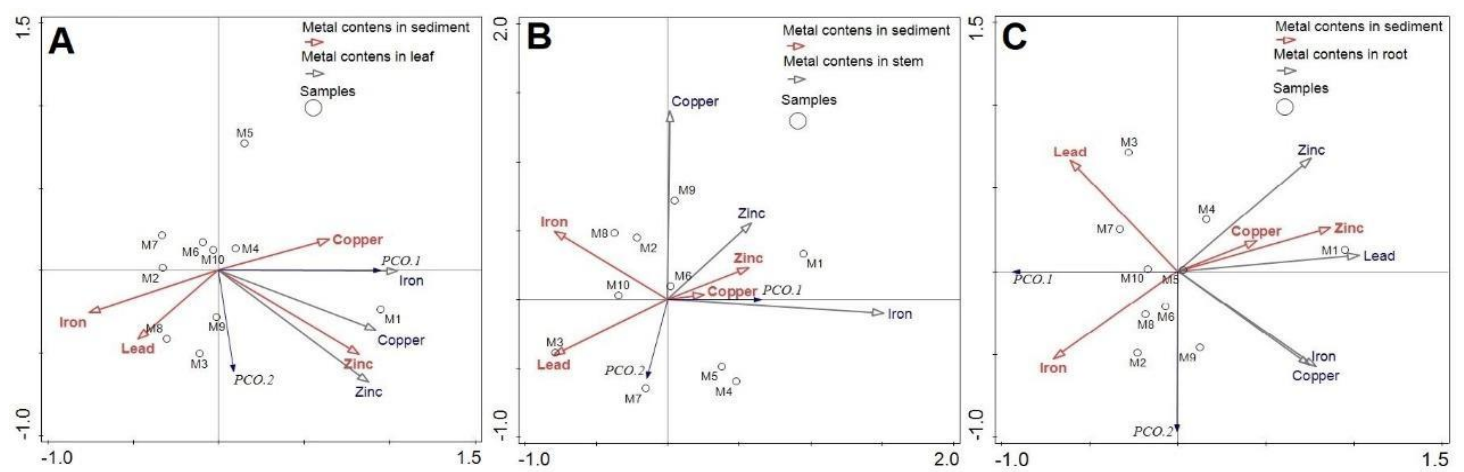

Figure 5. Redundancy analysis of correlations between metal content in parts of the plant A, $\mathrm{B}$ y $\mathrm{C}$ (blue lines), total metal concentrations in sediment (red lines) and vector direction of the first two coordinates (black lines).

For matrix correlations of element concentrations that bioaccumulate from the sediment to the stem, the loads for the first two coordinates of the redundancy analysis are lower. For the first coordinate, the explained percentage of pressure is 41.9 percent, and for the second coordinate 0.84 percent; these values indicate that there is apparently no correspondence between the distribution of observations for the element concentration matrices in the sediment and the element concentration in the stem. Figure 5B shows the distribution of the vectors and their direction either for the element variables in the sediment or in the stem, since no correlation slope is observed for any of the variables. In addition, Table 4 of the direct selection redundancy analysis for the case of the sediment with the stem indicates that none of the elements evaluated are affected in their distribution for both factors. That is, even at a significance level of 0.05 , we can infer that the concentrations of elements found in the stem are not a function of the concentrations of elements present in the sediment, and that these concentrations are probably a product of transfer from the root to the stem.

Finally, the correlation analysis of the matrices of element concentration in the sediment and root tend to have a better perspective, since the load of the coordinates in the analysis and redundancy are significantly higher than all other loads of the correlations evaluated. The first two coordinates have an explained cumulative variation of $87.84 \%$, having for the first coordinate an explained variation of $75.08 \%$ and $12.76 \%$ for the second coordinate. These values indicate that there is a better representativeness and a better adjustment of the matrices that explains the distribution of the observations and variables studied. In addition, a high degree of explained variation of the second component compared to the other one shows that interpretation for the $\mathrm{Y}$-axis is feasible, as shown in Figure 5C. This indicates that for the concentrations of elements in the root there is a positive correlation between $\mathrm{Fe}$ and $\mathrm{Cu}$, in addition to the positive correlation of $\mathrm{Pb}$ in the root and $\mathrm{Zn}$ in the sediment. The direct selection redundancy analysis in Table 4 shows the integration of all matrices for element concentration in the sediment and in the root. In addition, $\mathrm{Zn}$ is the only element that corresponds to its distribution for both the root and the sediment. That is, at a significance level of 0.05 , the $\mathrm{Zn}$ concentrations reported in the sediment tend to have a higher affinity for transfer to the root.

\section{CONCLUSIONS}

Polluted water treatment systems based on the use of aquatic plants have proven to be highly efficient in removing metals. H. ranunculoides showed phytoabsorbing potential for $\mathrm{Cu}$, $\mathrm{Zn}$ and Fe concentrations in its root, stem and leaves, which exceed the concentrations in plants in normal conditions. Taking into account each characteristic of the growth environment (water and sediment), in order of concentration Fe was significantly higher in all factors under study 
( $\mathrm{p}<0.05$ ), having the logical sequence of concentration $\mathrm{Fe}>\mathrm{Zn}>\mathrm{Cu}>\mathrm{Pb}$. Therefore, it is considered as a potential accumulator, mainly in the root of the majority of heavy metals investigated; the mechanism involved allows for the removal of heavy metals from water and sediments, except for $\mathrm{Pb}$, for which the capacity of the plant to absorb is not significant. However, there is a slope that the root absorbs much more $\mathrm{Pb}$ from the sediment, and this is not distributed along the leaf and stem. These results generate knowledge and contribute to the development of phytotechnologies oriented to the treatment of effluents contaminated with heavy metals to mitigate water pollution in wetlands.

\section{ACKNOWLEDGEMENTS}

The authors express their gratitude to the Laboratory of Chemistry and Environment of the Faculty of Applied Sciences of the Universidad Nacional del Centro del Perú for allowing us to make use of the equipment and materials for this study.

\section{REFERENCES}

AKSOY, A.; DUMAN, F.; SEZEN, G. Heavy Metal Accumulation and distribution in narrowleaved cattail (Typha angustifolia) and common reed (Phragmites australis). Journal of $\begin{array}{lllllll}\text { Freshwater Ecology, v. 20, n. 4, p. 783-785, } 2005 . & \text { n. }\end{array}$ https://doi.org/10.1080/02705060.2005.9664806

APHA; AWWA; WEF. Standard methods for the examination of water and wastewater. 22th ed. Washington DC, 2012. 1360 p.

CANADIAN COUNCIL OF MINISTERS OF THE ENVIRONMENT. Canadian Sediment Quality Guidelines for the Protection of Aquatic Life: Summary tables. Winnipeg, 2001.

CHATTERJEE, S.; CHETIA, M.; SINGH, L.; CHATTOPADHYAY, B.; DATTA, S.; MUKHOPADHYAY, S.K. A study on the phytoaccumulation of waste elements in wetland plants of a Ramsar site in India. Environmental Monitoring and Assessment, v. 178, p. 361-371, 2011. https://doi.org/10.1007/s10661-010-1695-x

CUADRADO, W.; CUSTODIO, M.; ESPINOZA, C.; VICUÑA, C.; URIBE, M. Capacity of absorption and removal of heavy metals from Scirpus californicus and Its potential use in the remediation of polluted aquatic environment. Open Journal of Marine Science, v. 9, n. 2, p. 74-85, 2019. https://doi.org/10.4236/ojms.2019.92006

GAN, Y.; WANG, L; YANG, G.; DAI, J.; WANG, R.; WANG, W. Multiple factors impact the contents of heavy metals in vegetables in high natural background area of China. $\begin{array}{llllll}\text { Chemosphere, } & \text { v. } & 184, & \text { n. } & 27, & 1388-1395,\end{array}$ https://doi.org/10.1016/j.chemosphere.2017.06.072

KABATA-PENDIAS, A. Trace elements in soils and plants. Boca Raton: CRC Press, 2011. https://doi.org/10.1201/b10158

KASTRATOVIĆ, V.; KRIVOKAPIĆ, S.; ĐUROVIĆ, D.; BLAGOJEVIĆ, N. Seasonal changes in metal accumulation and distribution in the organs of Phragmites australis (common reed) from lake Skadar, Montenegro. Journal of the Serbian Chemical Society, v. 78, p. 1241-1258, 2013. https://doi.org/10.2298/JSC121026153K 
KATZ, B. M.; MCSWEENEY, M. A multivariate kruskal-wallis test with post hoc procedures. Multivariate Behavioral Research, v. 15, n. 3, p. 281-297, 1980. https://doi.org/10.1207/s15327906mbr15034

KRAMER, U. Metal hyperaccumulation in plants. Annual review of plant biology, v. 61, p. 517-534, 2010. https://doi.org/10.1146/annurev-arplant-042809-112156

KRUSKAL, W.; WALLIS, W. Use of ranks in one-criterion variance analysis. Journal of the

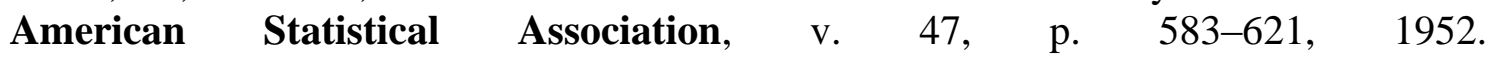
https://doi.org/10.1080/01621459.1952.10483441

LI, T. Q,; YANG, X. E.; LU, L. L.; ISLAM, E.; HE, Z. N. Effects of zinc and cadmium interactions on root morphology and metal translocation in a hyperaccumulating species under hydroponic conditions. Journal of Hazardous materials, v. 169, n. 1-3, p. 73474, 2009. https://doi.org/10.1016/j.jhazmat.2009.04.004

LEGENDRE, P.; ANDERSSON, M. Distance-based redundancy analysis: Testing multispecies responses in multifactorial ecological experiments. Ecological Monographs, v. 69, n. 1, p. 1-24, 1999. https://doi.org/10.1890/0012-9615(1999)069[0001:DBRATM]2.0.CO;2

LOJKO, R.; POLECHOŃSKA, L.; KLINK, A.; KOSIBA, P. Trace metal concentrations and their transfer from sediment to leaves of four common aquatic macrophytes. Environmental Science and Pollution Research, v. 22, p. 15123-15131, 2015. https://doi.org/10.1007/s11356-015-4641-1

NAZEER, S.; HASHMI, M. Z.; MALIK, R. N. Heavy metals distribution, risk assessment and water quality characterization by water quality index of the River Soan, Pakistan. $\begin{array}{llllll}\text { Ecological Indicators, } & \text { v. } & 43, & \text { p. } & 262-270,\end{array}$ http://dx.doi.org/10.1016/j.ecolind.2014.03.010

MARMIROLI, M.; ANTONIOLI, G.; MAESTRI, E.; MARMIROLI, N. Evidence of the involvement of plant ligno-cellulosic structure in the sequestration of $\mathrm{Pb}$ : An X-ray spectroscopy-based analysis. Environmental Pollution, v. 134, n. 2, p. 217-227, 2005. https://doi.org/10.1016/j.envpol.2004.08.004

MAZEJ, Z.; GERM, M. Trace element accumulation and distribution in four aquatic $\begin{array}{lllllll}\text { macrophytes. Chemosphere, v. 74, n. 5, p. 642-647, } 2009 . & \text {. }\end{array}$ https://doi.org/10.1016/j.chemosphere.2008.10.019

MIMBA, M. E.; OHBA, T.; NGUEMHE FILS, S. C.; NFORBA, M.T.; NUMANAMI, N.; BAFON, T. G.; AKA, F. T.; SUH, C. E. Regional geochemical baseline concentration of potentially toxic trace metals in the mineralized Lom Basin, East Cameroon: a tool for contamination assessment. Geochemical Transactions, v. 19, p. 1-17, 2018. https://doi.org/10.1186/s12932-018-0056-5

TWARDOWSKA, I.; KYZIOL, J. Sorption of metals onto natural organic matter as a function of complexation and adsorbent-adsorbate contact mode. Environment International, v. 28, n. 8, p. 783-791, 2003. https://doi.org/10.1016/S0160-4120(02)00106-X

VÄÄNÄNEN, K.; LEPPÄNEN, M. T.; CHEN, X. P.; AKKANEN, J. Metal bioavailability in ecological risk assessment of freshwater ecosystems: From science to environmental management. Ecotoxicology and Environmental Safety, v. 147, p. 430-446, 2018. https://doi.org/10.1016/j.ecoenv.2017.08.064 
WHO. Guidelines for drinking water quality. 2nd ed. Geneva, 1993.

YANG, J. X.; YE, Z. H. Metal accumulation and tolerance in wetland plants. Frontiers of Biology in China, v. 4, p. 282-288, 2009. https://doi.org/10.1007/s11515-009-0024-7

ZEVALlOS, W. T.; SALVATIERRA, L. M.; PÉREZ, L. M. Evaluación de los mecanismos de eliminación de $\mathrm{Pb} 2+$ en sistemas de fitorremediación en lotes operados con Salvinia biloba raddi (acordeón de agua). Energía, v. 13, n. 13, p. 9-17, 2015. 